тела обследовано 120 больных стабильной стенокардией напряжения II и III функционального класса. Больные были разделены на группы в зависимости от индекса массы тела. Выявлено, что избыточная масса тела по сравнению с нормальной достоверно ассоциируется с более высоким артериальным давлением в покое, более выраженной диастолической сердечной недостаточностью в виде увеличения объемов и массы миокарда левого желудочка с развитием эксцентрической гипертрофии по данным эхокардиографии.

Ключевые слова: стабильная стенокардия, индекс массы тела, сердечная недостаточность.

\title{
CHARACTERISTICS OF THE INSTRUMENTAL-LABORATORY PARAMETERS IN PATIENTS WITH ISCHEMIC HEART DISEASE AND INCREASED BODY WEIGHT
}

\section{V.K. Tashchuk, N.A. Turubarova-Leunova, O.P. Dinova, T.M. Amelina}

Abstract. For the purpose of determining specific characteristics and changes of instrumental-laboratory parameters, when performing physical activity in patients with chronic coronary heart disease, depending on the body weight, 120 patients with stable angina pectoris of the II ${ }^{\mathrm{nd}}$ and III- functional class were examinned. The patients were divided into groups based on the body mass index. It has been found out that excessive overweight compared with the normal one is, probably, associated with higher blood pressure at rest, more severe diastolic heart failure in the form of increased volumes and left ventricular myocardial mass with the development of eccentric hypertrophy according to echocardiographic findings.

Key words: stable angina, body mass index, heart failure.

Bukovinian State Medical University (Chernivtsi)

Рецензент - проф. Л.П. Сидорчук

Buk. Med. Herald. - 2013. - Vol. 17, № 2 (66). - P. 137-140

Надійшла до редакції 21.02.2013 року

(c) В.К. Тащук, Н.А. Турубарова-Леунова, О.П. Дінова, Т.М. Амеліна, 2013

УДК 616-005.4:599.323.4:615.015

\section{О.А. Ходаківський}

\section{ВПЛИВ АДЕМОЛУ НА ПОКАЗНИКИ ЕНЕРГЕТИЧНОГО ОБМІНУ В ГОЛОВНОМУ МОЗКУ ЩУРІВ ІЗ МОДЕЛЛЮ ГОСТРОЇ ЦЕРЕБРАЛЬНОЇ ІШЕМЇ̈}

Вінницький національний медичний університет ім. М.І. Пирогова

Резюме. У дослідах на щурах із модельним гострим порушенням мозкового крововиливу (білатеральна каротидна оклюзія) встановлено, що уведення похідного адамантану 1-адамантилетилокси-3-морфоліно-2пропанолу гідрохлориду (умовна назва адемол) у дозі 2 мг/кг внутрішньоочеревинно в лікувальному режимі (через 1 годину після інсульту, далі один раз на добу через кожні 24 год упродовж чотирьох діб ішемії) ліп-

Вступ. Лікування цереброваскулярних захворювань залишається однією з актуальних проблем. Ускладнення гострих порушень мозкового кровообігу (ГПМК) викликають тривалу непрацездатність, а нерідко й глибоку інвалідизацію осіб, що набуває важливого значення як у загальномедичному, так і в соціально-економічному аспектах [2].

Виразність нейродеструктивних процесів при ГПМК залежить від локального зниження кровопостачання і на першому етапі характеризується формуванням енергетичного дефіциту та лактат-ацидозу. Стан енергозабезпечення клітин мозку пов'язаний із рівнем макроергічних фосфатів - аденозинтрифосфорної (АТФ), аденозиндифосфорної (АДФ) та аденозинмонофосфорної кислот (АМФ). При цьому зміни вмісту аденіло-

( ) О.А. Ходаківський, 2013

140 ше ніж нейропротектор цитиколін сприяє зменшенню розладів вуглеводного та енергетичного обміну. Подібний ефект адемолу $є$ одним із ключових механізмів його захисної дії на ішемізовані нейрони мозку і вказує на перспективу для створення на його основі нового церебропротекторного засобу.

Ключові слова: адемол, ішемічний інсульт, цитиколін.

вих нуклеотидів випереджають зміни інших функціонально-метаболічних показників життєдіяльності клітини $[7,8]$. Тому пошук нових речовин, захисна дія в яких на нейрони головного мозку певним чином зумовлена модулювальним впливом на показники енергетичного обміну за церебральної ішемії $є$ актуальним завданням експериментальної фармакології. Однією з таких перспективних сполук, на нашу думку, може стати похідне адамантану 1-адамантилетилокси-3-морфоліно-2-пропанолу гідрохлорид (умовна назва адемол). За даними наших попередніх досліджень, адемол володіє захисною дією на ішемізований головний мозок [6].

Мета дослідження. Охарактеризувати вплив адемолу на зміни енергетичного обміну в головному мозку щурів за умов ГПМК. 
Матеріал і методи. Досліди проведено на білих щурах-самцях масою 160-170 г. Експериментальну модель ГПМК створювали шляхом двобічної перев'язки загальних сонних артерій до біфуркації [4]. Лігатури під судини підводили під пропофоловим наркозом (60 мг/кг внутрішньоочеревинно (в/о) «Fresenius Kabi», Австрія) і затягували в момент виходу тварин із наркозу. Через 1 год починали в/о уведення адемолу (2 мг/кг) та референспрепарату цитиколіну (250 мг/кг) у лікувальному режимі - через 1 год після ГПМК і далі кожні 24 год упродовж чотирьох діб ГПМК. Для оцінки порушень енергетичного обміну в ішемізованому мозку тварин (декапітація під пропофоловим наркозом) на 4-ту добу після моделювання необоротної білатеральної каротидної оклюзії (БКО) вилучали лобові частки головного мозку. У зазначений термін спостерігаються найбільш виразні метаболічні зміни в ішемізованому головному мозку [7]. Стан енергетичного та вуглеводного обміну вивчали за рівнем низки його інтермедіатів у гомогенатах мозку АТФ, АДФ, АМФ, лактату, пірувату та малату. Вміст аденілових нуклеотидів визначали за методом тонкошарової хроматографії [1], лактату - за методом Хохорста, пірувату - за методом ЦокаЛампрехта, малату - за методом Хохорста [3]. Результати обробляли статистично за допомогою програми Statistika 6.0 із використанням t-критерію Стьюдента.

Результати дослідження та їх обговорення. На моделі необоротної БКО у щурів встановлено, що наслідком ішемічного ушкодження стали зміни енергетичного гомеостазу тканини мозку, а саме дисбаланс макроергічних фосфатів. Відмічено значне зниження вмісту АТФ - до $44 \%$ від початкового рівня $(\mathrm{p}<0,05)$. Вміст АМФ в умовах експериментальної ішемії був вірогідно підвищений (у середньому на 250 \%) адекватно зниженню АТФ, що віддзеркалює посилену утилізацію останнього при ішемічному ураженні нервової тканини (табл.).

Адемол подібно до цитиколіну сприяв стабілізації енергетичного стану клітин мозку після церебральної ішемії, що підтверджувалося зростанням рівнів АТФ та АДФ на тлі зниження вмісту АМФ. Однак кількісні зміни АТФ більш чітко проявились у похідного адамантану. Так, курсове уведення щурам із ГПМК адемолу вірогідно збільшувало вміст у головному мозку АТФ порівняно 3 групою тварин, які отримували референспрепарат у середньому на 12,3 \% (табл.).

На думку багатьох авторів $[5,7,8]$, на стадії енергетичних порушень зниження вмісту АТФ в ішемізованій тканині головного мозку призводить до компенсаторної активації анаеробного гліколізу і посиленому утворенню лактату та іонів водню, що зумовлює розвиток метаболічного ацидозу.

Встановлено, що модельне ГПМК супроводжувалося розвитком декомпенсованого лактатацидозу - у гострому постішемічному періоді в головному мозку контрольних тварин відмічено

Таблиця

Показники енергетичного метаболізму та кислотно-лужної рівноваги в головному мозку щурів, лікованих адемолом або цитиколіном, на 4-ту добу гострого порушення мозкового кровообігу

$(\mathrm{M} \pm \mathbf{m} ; \mathbf{n}=7)$

\begin{tabular}{|c|c|c|c|c|}
\hline 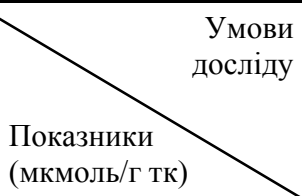 & $\begin{array}{l}\text { Інтактні тварини } \\
\text { (фоновий рівень) }\end{array}$ & $\begin{array}{c}\text { ГПМК+ 0,9\% } \mathrm{NaCl} \\
\text { (контроль) }\end{array}$ & $\begin{array}{c}\text { ГПМК + адемол } \\
(2 \mathrm{Mг} / \mathrm{к})\end{array}$ & $\begin{array}{c}\text { ГПМК + цитиколін } \\
\text { (250 мг/кг) }\end{array}$ \\
\hline АТФ & $2,16 \pm 0,04$ & $\begin{array}{c}0,95 \pm 0,03 * \\
(-56,0 \%)\end{array}$ & $\begin{array}{c}1,54 \pm 0,04 * \# \wedge \\
(-28,7 \%) \\
{[+62,1 \%]} \\
\end{array}$ & $\begin{array}{c}1,35 \pm 0,02^{* \#} \\
(-37,5 \%) \\
{[+42,1 \%]} \\
\end{array}$ \\
\hline АДФ & $0,43 \pm 0,004$ & $\begin{array}{c}0,20 \pm 0,011^{*} \\
(-54,5 \%)\end{array}$ & $\begin{array}{c}0,35 \pm 0,02^{* \#} \\
(-18,6 \%) \\
{[+75,0 \%]}\end{array}$ & $\begin{array}{c}0,31 \pm 0,01{ }^{*} \\
(-27,9 \%) \\
{[+55,0 \%]}\end{array}$ \\
\hline AM $\Phi$ & $0,2 \pm 0,01$ & $\begin{array}{c}0,70 \pm 0,015^{*} \\
(+250,0 \%)\end{array}$ & $\begin{array}{c}0,28 \pm 0,012^{* \#} \\
(+40,0 \%) \\
{[-50,0 \%]}\end{array}$ & $\begin{array}{c}0,29 \pm 0,013^{* \#} \\
(+45,0 \%) \\
{[-58,6 \%]}\end{array}$ \\
\hline Лактат & $2,41 \pm 0,04$ & $\begin{array}{c}14,96 \pm 0,16^{*} \\
(+520,7 \%)\end{array}$ & $\begin{array}{c}4,70 \pm 0,06^{* \# \wedge} \\
(+19,6 \%) \\
{[-68,6 \%]}\end{array}$ & $\begin{array}{c}6,73 \pm 0,013^{* \#} \\
(+214,6 \%) \\
{[-55,0 \%]}\end{array}$ \\
\hline Малат & $0,31 \pm 0,011$ & $\begin{array}{c}0,08 \pm 0,008^{*} \\
(-74,9 \%)\end{array}$ & $\begin{array}{c}0,26 \pm 0,012^{* \# \wedge} \\
(-16,1 \%) \\
{[+225,0]}\end{array}$ & $\begin{array}{c}0,20 \pm 0,011 \text { *\# } \\
(-35,5 \%) \\
{[+150,0 \%]}\end{array}$ \\
\hline Піруват & $0,41 \pm 0,013$ & $\begin{array}{c}0,10 \pm 0,005^{*} \\
(-75,6 \%)\end{array}$ & $\begin{array}{c}0,34 \pm 0,012^{* \# \wedge} \\
(-17,1 \%) \\
{[+240,0 \%]}\end{array}$ & $\begin{array}{c}0,23 \pm 0,008^{* \#} \\
(-44,0 \%) \\
{[+160,0 \%]}\end{array}$ \\
\hline
\end{tabular}

Примітка. ГПМК - гостре порушення мозкового кровообігу; ${ }^{*}-\mathrm{p}<0,05$ відносно інтактних тварин; ${ }^{*}-\mathrm{p}<0,05$ відносно контролю; ^ - p<0,05 відносно цитиколіну; У круглих дужках - відсотки зміни відповідного показника відносно його рівня в інтактних тварин, у квадратних дужках - відносно показника в групі контролю 
вірогідне підвищення рівня лактату в 6,2 раза на тлі зниження пірувату та малату практично в чотири рази (табл.).

Адемол та цитиколін вірогідно знизили на тлі БКО вміст лактату в середньому відповідно на $68,6 \%$ та 55 \% порівняно з контролем. При цьому на 4-ту добу спостереження рівень пірувату підвищився відносно контролю на $240 \%$ та $160 \%$, а вміст малату - відповідно на $225 \%$ та $150 \%(\mathrm{p}<0,05)$. Останне, на нашу думку, може свідчити про збільшення синтезу АТФ за рахунок аеробного та анаеробного шляхів окиснення. При загальній позитивній спрямованості коригувальної дії обох досліджуваних речовин на маркери ацидозу в нервовій тканині, за спроможністю зменшувати вміст лактату похідне адамантану вірогідно перевершувало референс-препарат у 1,4 раза, а концентрація малату та пірувату по відношенню до такої на тлі цитиколіну збільшилась у середньому відповідно на $23,1 \%$ та $32,4 \%$ $(\mathrm{p}<0,05)$.

Таким чином, адемол у щурів у гострому періоді ГПМК, порівняно із цитиколіном, чинив більш виразну дію на процеси аеробного та анаеробного окиснення вуглеводів i, як наслідок, сильніше підвищував енергетичний фонд нейронів.

Оцінюючи отримані результати, слід зазначити, що лікувальне курсове уведення щурам із ГПМК адемолу сприяло відновленню порушених енергетичних процесів та усувало метаболічний ацидоз на рівні цитиколіну або краще за нього, що $є$ однією 3 ланок механізму церебропротекторної дії досліджуваної сполуки. За ефективністю адемол у низькій дозі 2 мг/кг перевершує відомий церебропротектор цитиколін (250 мг/кг), що доводить вищу церебропротекторну активність нової сполуки.

Додатковою перевагою адемолу є його вища церебропротекторна активність, оскільки в умовно ефективній дозі 2 мг/кг він перевершує цитиколін (250 мг/кг).

\section{Висновки}

1. Чотириденне лікування щурів із модельною церебральною ішемією адемолом або цитиколіном сприяє відновленню порушених процесів енергетичного обміну та усуває метаболічний ацидоз в ішемізованому головному мозку.

2. За здатністю нормалізувати вміст аденозинтрифосфату, малату та пірувату в ішемізова- ному головному мозку адемол вірогідно перевершує цитиколін.

3. Зменшення розладів вуглеводного та енергетичного обміну при порушенні мозкового кровообігу адемолом є одним із механізмів його церебропротекторної дії.

Перспективи подальших досліджень. Адемол можна вважати перспективним церебропротектором. Оскільки в ланцюгу ішемічних патохімічних змін у нейронах важливе місце належить розвитку нітрозативного стресу та інтенсифікації процесів вільнорадикального окиснення, перспективним $є$ дослідження його впливу на ці процеси.

\section{Література}

1. Захарова Н.В. Тонкослойная хроматография нуклеотидов эритроцитов на пластинах Силуфол / Н.В. Захарова, В.И. Рубин // Лаб. дело. - 1980. № 12. - С. 735-738.

2. Зозуля I.C. Сучасний стан проблеми діагностики, перебігу, лікування гострих порушень мозкового кровообігу в поліклінічних умовах (огляд літератури) / І.С. Зозуля, Г.І. Лисенко, І.О. Латоха // Укр. мед. часопис. -2011 . - Т. 11-12, № 6. - С. 30-38.

3. Прохорова М.И. Современные методы биохимических исследований (липидный и энергетический обмен) / Прохорова М.И. - Л.: Изд-во Ленинградского университета, 1982. $-272 \mathrm{c}$.

4. Руководство по экспериментальному (доклиническому) изучению новых фармакологических веществ / Под общ. ред. Р.У. Хабриева. - [2-е изд., перераб. и доп.]. - М.: ОАО «Издательство «Медицина», 2005. -832 c.

5. Трошин В.Д. Острые нарушения мозгового кровообращения : руководство / В.Д. Трошин, А.В. Густов. [3-е изд., перераб. и доп.]. - М.: ООО "Медицинское информационное агентство", 2006. - 432 с.

6. Ходаківський О.А. Оцінка впливу експериментальної терапії адемолом на інтенсивність перебігу деструктивних змін в мембранах нейронів у монгольських піщанок в умовах гострої церебральної ішемії / О.А. Ходаківський // Вісн. морфол. - 2011. - Т. 17, № 1. C. 62-65.

7. Шведський В.В. Вплив діакамфу гідрохлориду на показники енергетичного обміну в головному мозку щурів із моделлю церебральної ішемії на тлі цукрового діабету / В.В. Шведський, С.Ю. Штриголь, С.I. Мерзлікін // Клін. фармація. - 2011. - Т.15, № 3. C. 57-61.

8. Malate-aspartate shunt in neuronal adaptation to ischemic conditions: molecular-biochemical mechanisms of activation and regulation / I.F. Belenichev, Yu.M. Kolesnik, S.V. Pavlov [et al.] // Neurochemical Journal. - 2012. Vol. 6, № 1. - P. 22-28.

\section{ВЛИЯНИЕ АДЕМОЛА НА ПОКАЗАТЕЛИ ЭНЕРГЕТИЧЕСКОГО ОБМЕНА В ГОЛОВНОМ МОЗГЕ КРЫС НА МОДЕЛИ ОСТРОЙ ЦЕРЕБРАЛЬНОЙ ИШЕМИИ}

\section{А.А. Ходаковский}

Резюме. В опытах на крысах с модельным острым нарушением мозгового кровообращения (билатеральная каротидная окклюзия) установлено, что введение производного адамантана 1-адамантилетилокси-3-морфолино-2пропанола гидрохлорида (условное название адемол) в дозе 2 мг/кг внутрибрюшинно в лечебном режиме (через 1 час после моделирования инсульта и далее один раз в сутки через каждые 24 ч в течение 4 дней) лучше церебропротектора цитиколина способствует уменьшению расстройств углеводного обмена. Подобный эффект адемола является одним из ключевых механизмов его защитного действия на ишемизированные нейроны головного мозга и указывает на перспективу для создания на его основе нового церебропротекторного препарата.

Ключевые слова: адемол, ишемический инсульт, цитиколин. 


\section{THE INFLUENCE OF ADEMOL ON THE INDICES OF ENERGY METABOLISM IN THE RAT BRAIN WITH A MODEL OF ACUTE CEREBRAL ISCHEMIA}

\section{O.A. Khodakivskyi}

Abstract. In experiments on rats with a model acute disorder of the cerebral circulation (bilateral carotid occlusion) it has been established that the introduction of a derivative adamantane 1-adamantiletiloxy-3-morpholino-2 propanol hydrochloride (under a conventional name ademol) in a dose of $2 \mathrm{mg} / \mathrm{kg}$ intraabdominally in the treatment mode (in an hour after insult and further 1 time per diem in every 24 hours during 4 days of cerebral ischemia) better than the cerebral protector cytikolin contributes to a decrease of disorders of carbohydrate and energy metabolism. A similar effect of ademol is one of the key mechanisms of its protective influence on ischemized neurons of the brain, pointing out to its perspective for the creation on its basis of a new cerebroprotective agent.

Key words: ademol, ischemic insult, cytikolin.

M.I. Pyrohov National Medical University (Vinnytsia)

Рецензент - проф. I.I. Заморський

Buk. Med. Herald. - 2013. - Vol. 17, № 2 (66). - P. 140-143

Надійшла до редакції 11.02.2013 року

(c) О.А. Ходаківський, 2013

УДК 616-005.2:57.063.8]-039(477.54)

\section{О.С. Шевченко}

\section{ПРОФИЛИ РЕЗИСТЕНТНОСТИ ВЫДЕЛЕННЫХ ШТАММОВ M.TUBERCULOSIS В ХАРЬКОВСКОЙ ОБЛАСТИ}

Харьковский национальный медицинский университет

Резюме. Целью данного исследования явилось определить соотношение между чувствительными и устойчивыми штаммами M. tuberculosis, выделенными от пациентов с эпидемиологически опасной легочной формой туберкулеза. Были проанализированы результаты исследования устойчивости микобактерий туберкулеза (МБТ) к противотуберкулезным препаратам (ПТП) у больных туберкулезом легких (ТБ) зарегистрированных в 2009-2010 гг. по Харьковской области. Ана-

Введение. Угроза распространения лекарственно устойчивого туберкулеза сегодня рассматривается как очень значительная. Самую серьёзную опасность представляет мультирезистентный туберкулёз (МРТБ), который вызывается штаммами, обладающими устойчивостью, по крайней мере, к изониазиду и рифампицину двум основным лекарственным препаратам первого ряда, используемым в комбинированной химиотерапии. Несмотря на различное толкование имеющихся данных, распространяемость мультирезистентного туберкулёза была охарактеризована как глобальная пандемия, ещё более смертельная, чем синдром приобретённого иммунодефицита, и потенциально способная дестабилизировать общество [6].

Степень опасности велика по двум причинам. Во-первых, количество пациентовносителей устойчивых форм возросло до таких размеров, что поставило под угрозу контроль ТБ в некоторых частях мира. По оценкам ВОЗ в период между 2011 и 2015 гг., будет выявлено более чем 2 миллиона новых случаев заболевания лиз показал неблагоприятную тенденцию увеличения суммарной частоты медикаментозной устойчивости МБТ и утяжеление ее структуры. Особенностью современной эпидемиологической ситуации по туберкулезу является возрастание частоты первичной лекарственной устойчивости.

Ключевые слова: туберкулез, лекарственная устойчивость, эпидемиология.

МРТБ. Согласно последним данным ВОЗ, ежегодно в мире выявляют около 450000 новых случаев МРТБ, причем на такие страны, как Китай, Индия и Россия приходится более 50 \% всех случаев в мире. Менее $5 \%$ новых и ранее лечившихся пациентов с туберкулезом были протестированы на МРТБ в большинстве стран мира в 2010 году и зарегистрированное число пациентов, проходящих лечение, достигло только $16 \%$ [7].

Лечение лекарственно устойчивых форм заболевания отчасти осложнено тем, что оно связано с использованием дорогостоящих и токсичных медикаментов [4]. При этом страны с низкими доходами, сообщают о дефиците финансирования на 2012 год в 1 млрд. долларов США. Только 5 \% больных мультиустойчивым туберкулезом в мире получают надлежащее лечение. Вторая причина состоит в том, что пациенты с активным ТБ, включая и устойчивую к антибиотикам форму, становятся всё более мобильными в международном масштабе. Глобализация влияет на распространение инфекционных заболеваний, и 